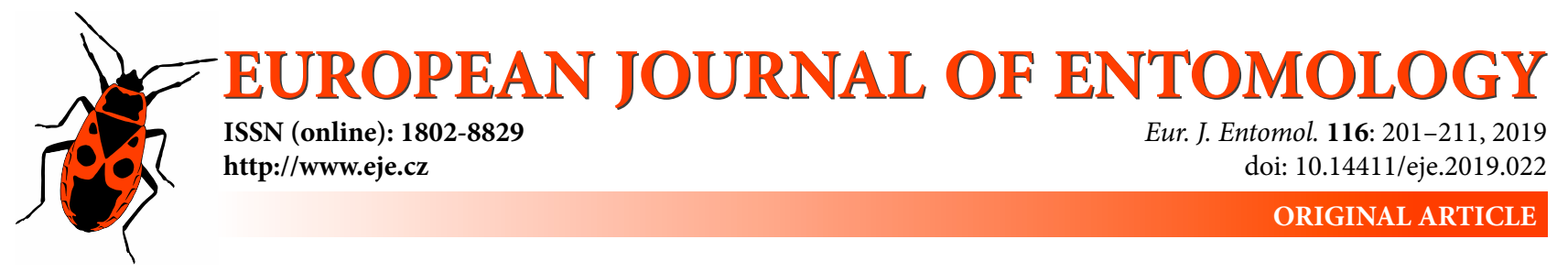

\title{
Coniophloeus, a new genus of Embrithini from South Africa, with description of four new species (Coleoptera: Curculionidae: Entiminae)
}

\author{
ROMAN BOROVEC \\ Czech University of Life Sciences Prague, Faculty of Forestry and Wood Sciences, Department of Forest Protection and \\ Entomology, Kamýcká 1176, 16521 Praha 6 - Suchdol, Czech Republic; e-mail: romanborovec@mybox.cz
}

Key words. Curculionidae, Entiminae, Embrithini, Coniophloeus, new genus, new species, South Africa

Abstract. A new genus, Coniophloeus gen. n., is described for five species of South African weevils known from the Western and Eastern Cape and assigned to the tribe Embrithini Marshall, 1942: Coniophloeus squalidus (Boheman, 1842) comb. n. (type species, transferred from the genus Trachyphloeus Germar, 1817 and tribe Trachyphloeini Lacordaire, 1863), C. alternans sp. n., C. oberprieleri sp. n., C. robustus sp. n. and C. obrieni sp. n. All five species are illustrated and keyed.

ZooBank Article LSID: F6DEACAD-1127-4A2D-8E9C-6923069EF96F

\section{INTRODUCTION}

The tribe Embrithini Marshall, 1942, as redefined by Borovec \& Oberprieler (2013), currently comprises 67 genera. Almost all known species of Embrithini are arboricolous or floricolous, active during the day on plants, shrubs or trees. There are some exceptions only in several South African embrithine genera, whose species live among litter under plants, such as some undescribed species of Cycliscus Schoenherr, 1842 and Glyptosomus Schoenherr, 1847 as well as Ellimenistes humeralis Marshall, 1947 and three similar undescribed species. The only described genus in which all the species are terricolous is Afrophloeus Borovec \& Oberprieler, 2013, which comprises three South African species, one of them introduced to Australia. However, there are several other terricolous species among as yet unidentified material, which are also assignable to Embrithini but can not be accommodated in any described genus, for example those described from the Afrotropical region in the Palaearctic tribe Trachyphloeini (Borovec \& Skuhrovec, 2017). One such species is Trachyphloeus squalidus Boheman, 1842, which is here removed from Trachyphloeus Germar, 1817 and Trachyphloeini Lacordaire, 1863. The description of a new genus and discussion of its taxonomic position are the aims of the present paper.

The change in lifestyle from floricolous or arboricolous to living in soil or litter have to include also some morphological changes to the body, mainly shortening of extremities, which can be also more robust, diminution in their eyes and others. These changes are very apparent if one compares the floricolous genus Lalagetes Schoenherr, 1842, with the strictly terricolous genus Afrophloeus, both belonging to Embritihini. Lalagetes species have slender antennae and legs, scapes 4.6-6.1 $\times$ and protibiae 5.5-6.6× longer than wide at widest point, and eyes in lateral view large, with the diameter distinctly longer than the part of head below them, while Afrophloeus species have short and robust antennae, scapes $2.4-3.7 \times$ and protibiae $3.3-$ $3.7 \times$ longer than wide at widest point, and eyes in lateral view small, with the diameter distinctly shorter than the part of head below them. Moreover, terricolous species of Afrophloeus have an apical portion of protibiae lobed and armed with distinct, stout spines and dorsal body vestiture formed by short erect spatulate setae, while the species of Lalagetes have the apex of protibiae rounded and fringed by fine setae and body dorsally covered by long and slender erect setae.

\section{MATERIAL AND METHODS}

Body length of all specimens was measured in dorsal view from the anterior border of the eyes to the apex of the elytra, excluding the rostrum. Width/length ratio of the rostrum was measured as the maximum width at the base versus the maximum length to the base of the mandibles. Width/length ratios of pronotum, elytra, antennal and tarsal segments were taken at the maximum width and length of the respective parts in dorsal view; length of the onychium was taken as the part exceeding the outline of tarsal segment 3. Dissected male and female genitalia were studied in glycerine. Female genitalia were afterwards embedded in 


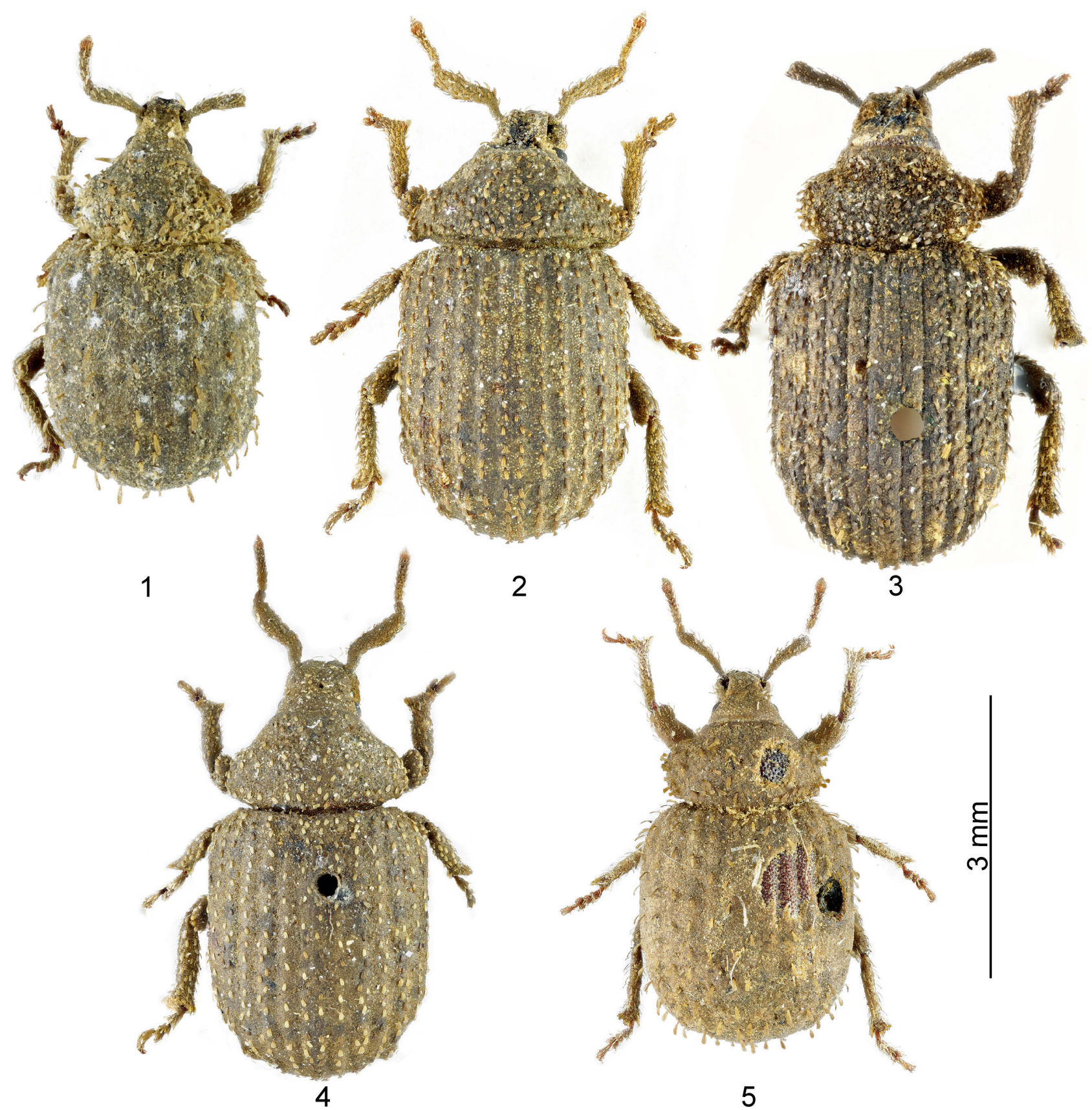

Figs 1-5. Habitus of Coniophloeus species: 1 - Coniophloeus alternans sp. n., holotype male; 2 - C. oberprieleri sp. n., holotype female; $3-C$. obrieni sp. n., holotype male; $4-C$. robustus sp. n., paratype female; $5-C$. squalidus (Boheman), female.

Solakryl BMX (epoxy resin soluble in toluene; Medika, Prague) and male genitalia were mounted dry on the same card as the respective specimen, with tegmen and sternite IX embedded in Solakryl BMX. Habitus images were taken with a Canon EOS 5D Mark II camera fitted with a Canon MP-E65 1-5× macro lens. Images were stacked using the program Zerene Stacker and edited in Adobe Photoshop CC 2015.

The terminology used to describe the rostrum and the genitalia follows Oberprieler et al. (2014).

Exact label data of type material are cited; with different labels indicated by a slash (/). Author's remarks and comments are given in square brackets.

Specimens are deposited in the following museums and private collections: BMNH - Natural History Museum, London, United Kingdom (British Museum of Natural History), Max Bar- clay; MNBG - Museum für Naturkunde der Humboldt Universität, Berlin, Germany, Manfred Uhlig; NHRS - Naturhistoriska Riksmuseet, Stockholm, Sweden, Johannes Bergsten; SANC - National Collection of Insects, Pretoria, South Africa, Riaan Stals; SDEI - Senckenberg Deutsches Entomologisches Institut, Müncheberg, Germany, Lutz Behne; TMSA - Ditsong National Museum of Natural History (formerly Transvaal Museum), Pretoria, South Africa, Ruth Müller.

\section{TAXONOMY}

\section{Genus Coniophloeus gen. $\mathbf{n}$.}

(Figs 1-38)

ZooBank taxon LSID:

8D5D314D-3A3B-43AB-BCC7-CACD2D62778D 
Type species. Trachyphloeus squalidus Boheman in Schoenherr, 1842: 110, here designated.

Diagnosis. Small to medium-sized Embrithini, 3.2-5.6 $\mathrm{mm}$ long, with head and rostrum separated by shallow to deep, transverse furrow and rostrum weakly rounded around antennal sockets at apical half; head in lateral view obliquely declivous to base of epifrons; scapes robust; clubs small, not clearly separated from funicle; pronotum conspicuously transverse, 1.7-2.2 $\times$ wider than long, creating dorso-ventrally flattened, laterally prominent longitudinal ridges; protibiae short and robust, at apex laterally enlarged with variable number of spines, spines on outer portion connected; metatibiae with well developed, squamous corbels; claws connate basally; ventrite 2 in middle about as long as ventrites 3 and 4 combined; tegmen with parameres; plate of sternite VIII of female umbrella-shaped with membranous basal margin and apodeme terminating inside it.

Description (Figs 1-38). Body length 3.2-5.6 mm. Body (Figs 1-5) dark brownish to blackish, in some species tarsi or only spines at apex of tibiae, claws and antennal club brownish. Dorsal and ventral part of body densely covered with oval to rounded, small, appressed scales, 6-8 scales across width of one interstria, scales longitudinally finely striate, dense, hiding integument or partly isolated. Scapes, funicles, femora, tibiae and tarsi densely covered by identical appressed scales, only clubs shortly and densely setose. Elytra with each interstria having 1-2 dense rows of subspatulate, conspicuous, appressed to semi-erect setae; pronotum, head with rostrum, antennae except club and legs with similar but more slender and shorter, densely irregularly scattered setae, semi-appressed to semi-erect.

Rostrum (Figs 6, 7, 12, 13, 18, 19, 22, 23, 31, 32) 1.1$1.8 \times$ wider than long, apical half rounded; in lateral view distinctly convex. Epifrons at base as wide as or narrower than distance between eyes, tapering anteriorly with concave and somewhat swollen edges, longitudinally deepened, posteriorly separated from head by transverse shallow to deep sulcus, often covered by vestiture. Epifrons beneath scales longitudinally distinctly and regularly impressed, in transverse profile V-shaped, its posterior corners in dorso-lateral view distinctly prominent, creating blunt notches; base of epifrons arched or straight, sharply, tooth-like constricted to form transverse and sometimes a very deep furrow separating it from head. Frons short, squamous, bearing 3-4 pairs of stout setae. Epistome moderately large, V-shaped, posteriorly sharply and narrowly carinate, not reaching anterior border of scrobes, not squamous. Antennal scrobes in dorsal view scarcely or partly visible, if visible then reniform; in lateral view short, weakly curved, directed just towards eyes, separated from anterior margin of eye by slender or wide squamous stripe. Vertex flat and wide, beneath scales with numerous, sometimes ill-defined longitudinal striae radiating from middle of base of epifrons. Head in lateral view flat, distinctly obliquely declivous to transverse furrow separating head from epifrons. Eyes small, circular in outline, convex, weakly prominent from outline of head, in lateral view placed at middle of head height. Mandibles small, not squamous, trisetose but most of specimens without setae, which were possibly abraded; in two specimens with setal remnants. Submentum with two long setae.

Antennae robust, with scape (Figs 6, 12, 18, 22, 31) moderately to very robust, wide, slightly exceeding anterior margin of pronotum when at rest, longer than funicle, in some species strongly S-shaped at base, enlarged apically, widest at apex or at anterior third, at apex wider than club and equally as wide as protibiae at midlength; funicle 7-segmented, funicular segments wide and short, segments 1 and 2 conical, the others transverse; club small, in some species barely wider than last funicular segments.

Pronotum (Figs 1-5) conspicuously transverse, 1.68$2.24 \times$ wider than long, only slightly narrower than elytra, widest in posterior half where it is dorso-laterally flattened, laterally weakly prominent longitudinal flattened tubercles; sides rounded; anterior margin distinctly narrower than posterior one, pronotum behind anterior margin with significant constriction. Disc regularly convex, without tubercles, furrows or depressions, beneath scales finely, densely and regularly granulate, moderately shiny. Base weakly arched. Anterior border in lateral view straight, without ocular lobes or setae. Procoxal cavities contiguous, rounded, nearer to anterior border of prosternum; procoxae subglobular. Scutellum not visible.

Elytra (Figs 1-5) subparallel-sided, 1.16-1.31× longer than wide, base weakly arched, humeral calli regularly rounded, post humeral calli absent, apex widely rounded, 10 -striate, striae narrow, punctate with punctures hidden below scales, interstriae vaulted, wide, beneath scales finely and densely granulate. Mesocoxae semiglobular, mesosternal process narrower than quarter of diameter of mesocoxa. Metacoxae transverse, separated by shorter distance than transverse diameter of metacoxa.

Femora unarmed, distinctly inflated. Tibiae short and robust; protibiae (Figs 8, 14, 20, 24, 33) at apex enlarged laterally, mesally rounded or slightly lobed, with different number of differently coloured short spines, lateral widened part armed with 3-4 connected, laterally prominent spines, inner corner with short mucro; mesotibiae densely fringed with numerous short yellowish spines and with one inner curved mucro; metatibiae with large, subtriangular apical surface glabrous or squamous, with mucro; metatibial corbels wide and well distinct, densely squamous, fringed outside and inside by dense and very short yellowish to brownish setae. Tarsi wide to slender, segment 3 wider than segment 2, bilobed, onychium long; claws long, fused in basal third, then divaricate. Underside of tarsi densely finely setose.

Abdomen (Fig. 34) ventrally subtriangular, 1.03-1.12× longer than wide; ventrite 1 large, in middle about equally long as ventrites $2-4$ combined, behind metacoxae equally long as ventrite 2; ventrite 2 in middle about as long as ventrites 3 and 4 combined; ventrite 5 in males shorter, subtrapezoidal, in females longer, subtriangular. Suture between ventrites 1 and 2 slightly sinuate to straight, finer and narrower than the others; suture between ventrites 3 and 4 


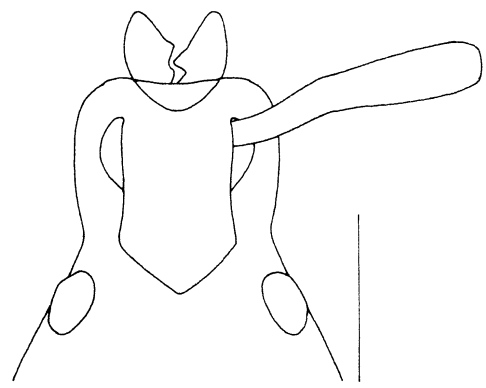

6

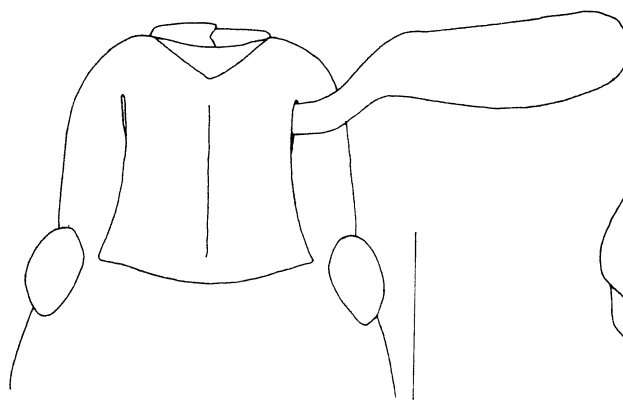

12

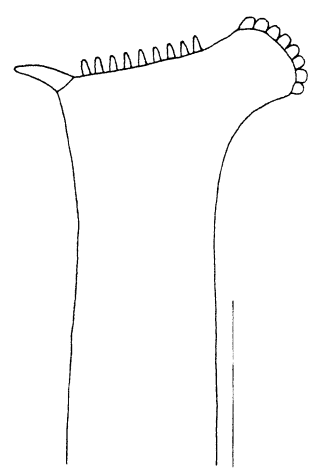

14

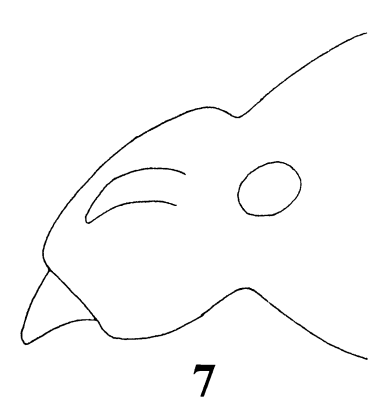

7

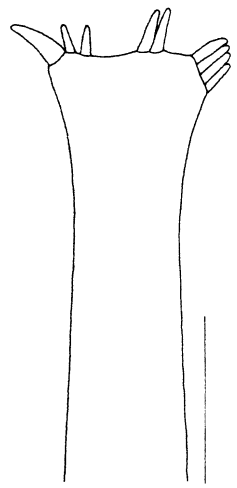

8

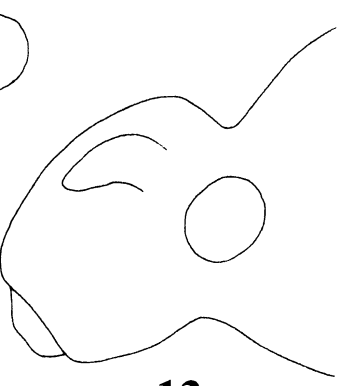

13

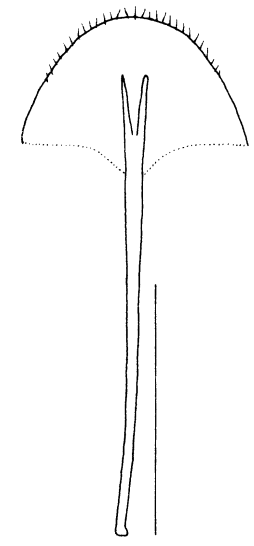

16

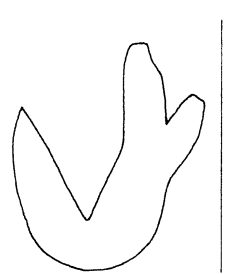

15

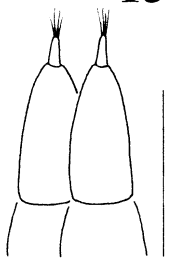

17

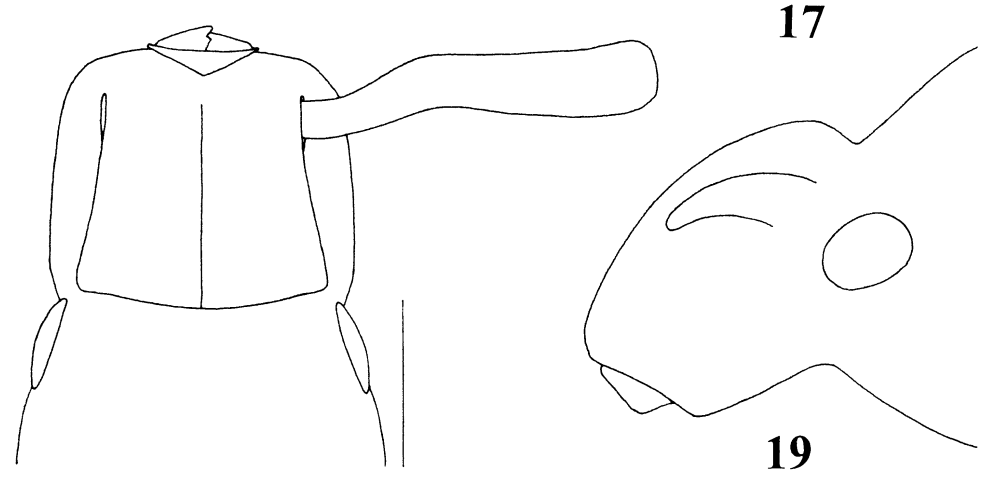

18

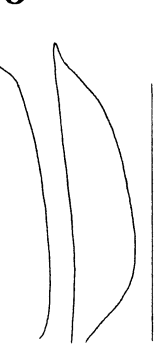

9

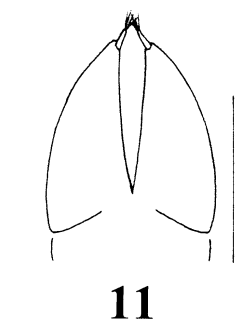

10

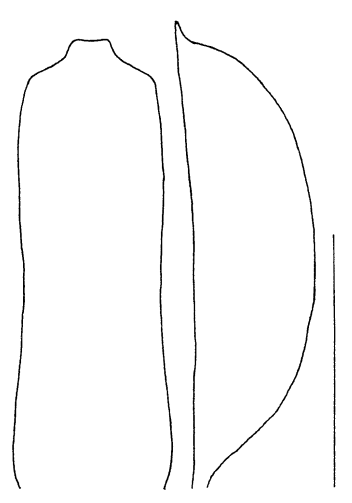

21

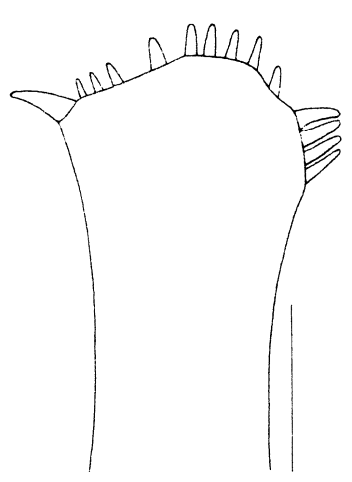

20

Figs 6-21. Structural details of Coniophloeus gen. n. Figs 6-11: Coniophloeus alternans sp. n. 6 - head with rostrum, dorsal view, scale $=1 \mathrm{~mm} ; 7$ - head with rostrum, lateral view, scale as in dorsal view; 8 - apex of right protibia, scale $=0.50 \mathrm{~mm} ; 9-$ penis in ventral and lateral view, scale $=0.50 \mathrm{~mm} ; 10$ - sternite VIII of female, dorsal view, scale $=0.50 \mathrm{~mm} ; 11-$ ovipositor, dorsal view, scale $=0.25 \mathrm{~mm}$. Figs 12-17: C. oberprieleri sp. n. 12 - head with rostrum, dorsal view, scale $=1 \mathrm{~mm} ; 13$ - head with rostrum, lateral view, scale as in dorsal view; 14 - apex of right protibia, scale $=0.50 \mathrm{~mm} ; 15-$ spermatheca, scale $=0.50 \mathrm{~mm} ; 16-$ sternite VIII of female, dorsal view, scale $=$ $0.50 \mathrm{~mm} ; 17$ - ovipositor, dorsal view, scale $=0.25 \mathrm{~mm}$. Figs $18-21$ : C. obrieni sp. $\mathrm{n}$. $18-$ head with rostrum, dorsal view, scale $=1 \mathrm{~mm}$; 19 - head with rostrum, lateral view, scale as in dorsal view; 20 - apex of right protibia, scale $=0.50 \mathrm{~mm}$; $21-$ penis in ventral and lateral view, scale $=0.50 \mathrm{~mm}$. 
slightly arched, between ventrites 4 and 5 distinctly arched. Ventrites with dense oval appressed scales and with semierect short to long subspatulate setae. Metaventral process obtuse, narrower than transverse diameter of metacoxa.

Male genitalia. Penis (Fig. 25) short to long, well sclerotized, temones 1.8-2.2 $\times$ longer than body of penis and 2.5-2.8 $\times$ longer than tegminal manubrium; endophallus with complex of long and branched sclerites, because of limited material of most species, sclerites described only in O. robustus sp. n. Tegmen (Fig. 26) with slender ring with long parameres connected at base, manubrium 1.1-1.4× longer than diameter of ring, slightly enlarged apically. Sternite IX (Fig. 27) with spiculum gastrale moderately long, anteriorly curved and tapered, posteriorly with fused basal arms; hemisternites slender, comma-shaped.

Female genitalia. Gonocoxites (Figs 11, 17, 30, 38) short, flat, subtriangular, regularly tapered apically, with apical short or long styli, with tuft of 3-4 setae. Sternite VIII (Figs 10, 16, 29, 37) with moderately long apodeme, 2.3-2.9 $\times$ longer than plate, terminating just inside plate; plate wide, umbrella-shaped, with basal margin ill-defined and apical margin slender, but developed, with short setae. Spermatheca (Figs 15, 28, 36) C-shaped, with irregularly curved cornu and developed ramus and nodulus, differently shaped between the species.

Etymology. The genus name is derived from the Greek nouns kónis (dust), referring to the dusty appearance of the body, and the Greek word phloio (bark) as used in the compound name of the morphologically superficially similar genus Trachyphloeus, the name under which most of the specimens considered here were originally deposited in collections. The name is masculine in gender.

Biology. Unknown, there are no data where collected except for O. robustus sp. n., which was sifted from forest litter.

Distribution. The genus is known only from South Africa (the Western and Eastern Cape provinces).

Remarks. This genus includes five species, four of them newly described below. The species of Coniophloeus resemble large species of Trachyphloeus or other Trachyphloeini, but are easily distinguishable mainly by the wide, squamous metatibial corbels and from Trachyphloeus by the distinct transverse sulcus between head and rostrum (rostrum continuous with head in Trachyphloeus), connate tarsal claws (free claws), tegmen with parameres (lacking parameres) and sternite VIII with apodeme terminating inside plate with ill-defined posterior border (apodeme creating distinct basal margins of plate). The first three characters (presence of corbel, sulcus between head and rostrum and tarsal claws connate in basal third), combined with the trisetose mandibles and dorso-laterally placed scrobes, indicate that the newly described genus belongs to the tribe Embrithini.

Within the Embrithini Coniophloeus gen. n. and Afrophloeus are the only Embrithini with short and robust antennae and very wide and short scapes, short and robust tibiae and laterally enlarged protibiae with apices armed with moderately long spines. Coniophloeus gen. n. can be distinguished from Afrophloeus by the following characters:

Afrophloeus: Apex of protibiae rounded with single laterally prominent spine. Elytra with small subhumeral tubercles visible in dorso-lateral view. Eyes flat. Metaventral process $1.5 \times$ as wide as transverse diameter of metacoxa. Suture between ventrite 3, 4 and 5 straight. Tegmen lacking parameres. 2.3-3.3 $\mathrm{mm}$.

Coniophloeus gen. n.: Outer surface of apex of protibiae distinctly enlarged and with 3-4 connected, laterally prominent spines. Elytra without subhumeral tubercles. Eyes protruding. Metaventral process narrower than transverse diameter of metacoxa. Suture between ventrite 3,4 and 5 arched. Tegmen with long parameres. $3.2-5.6 \mathrm{~mm}$.

Coniophloeus is similar to embrithine genera with small species, such as Glyptosomus Schoenherr, 1847, Heisonyx Marshall, 1947, Lalagetes Schoenherr, 1842 and Phaylomerinthus Schoenherr, 1842. From Glyptosomus it differs by the following characters:

Glyptosomus: Head and rostrum in profile at the same level. Sulcus between head and rostrum in dorsal view clearly defined. Eyes with supraocular longitudinal tubercles. Protibiae laterally straight, apically fringed with short, inconspicuous, regularly spaced spines. Ventrite 1 at least $5 \times$ as long as ventrite 2 ; ventrite 2 as long as ventrite 3 or $4.2 .7-5.4 \mathrm{~mm}$.

Coniophloeus gen. n.: Head and rostrum in profile clearly separated by transverse furrow. Sulcus between head and rostrum in dorsal view with ill-defined margins. Eyes without supraocular tubercles. Protibiae laterally enlarged, apically armed with conspicuous spines, united with inner, middle and outer groups, outer spines connected. Ventrite 1 twice as long as ventrite 2 ; ventrite 2 as long as ventrite 3 and 4 combined. $3.2-5.6 \mathrm{~mm}$.

Coniophloeus differs from Heisonyx, Lalagetes and Phaylomerinthus by the following characters: epifrons posteriorly separated from head by a wide transverse sulcus with ill-defined borders (clearly defined narrow sulcus in Heisonyx, Lalagetes and Phaylomerinthus); frons densely squamous (glabrous); scapes short and robust (long and slender); funicular segments 3-7 short and transverse (long and slender); clubs barely wider and hardly separated from last funicular segments (distinctly wider and well separated from last funicular segments); pronotum short and wide, at least $1.7 \times$ wider than long (narrower, at most $1.5 \times$ wider than long); apex of protibiae widened laterally, apically with distinct spines (straight laterally, apically with fringe of setae or short spines) and metatibiae with broad, distinct corbels (corbels slender, sometimes barely visible).

Coniophloeus squalidus (Boheman, 1842), comb. $\mathbf{n}$. (Figs 5, 31-38)

Trachyphloeus squalidus Boheman in Schoenherr, 1842: 110 (original description); Seidlitz 1868: 97 (monograph of Otiorhynchinae); Lona 1937: 332 (catalogue); Borovec \& Meregalli, 2013: 501 (note); Borovec \& Skuhrovec, 2017: 539 (lectotype designation).

Type locality. Terra Caffrorum [South Africa, Eastern Cape]. 


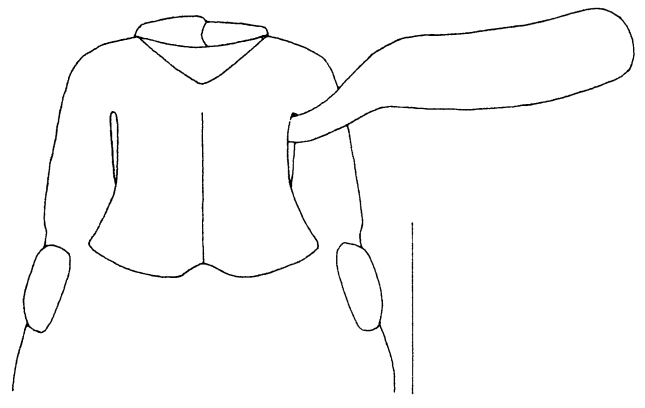

22
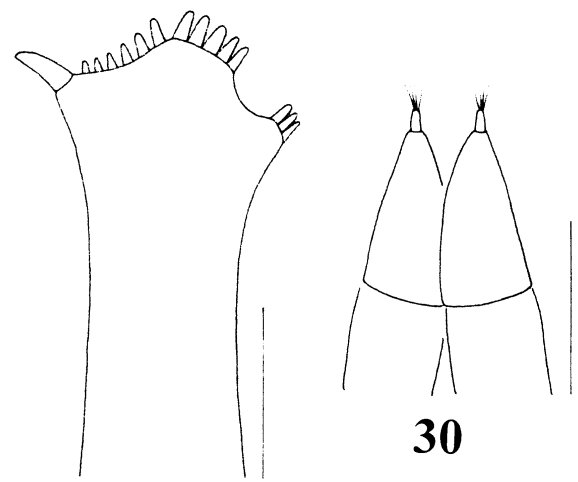

30

24

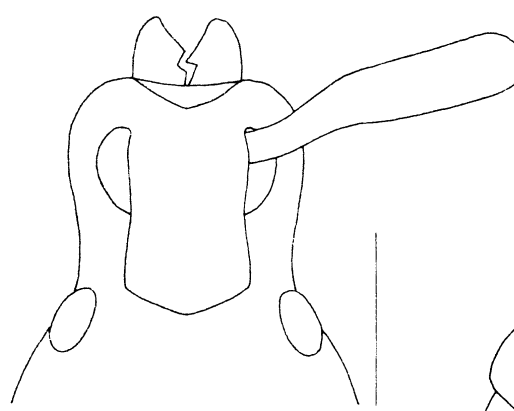

31

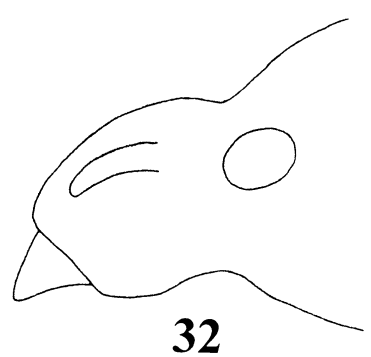

32

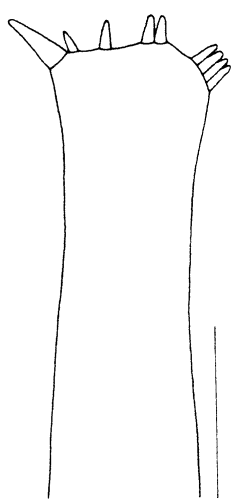

33

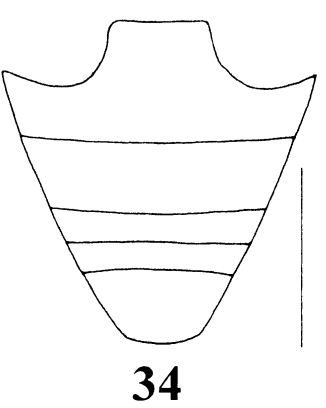

34

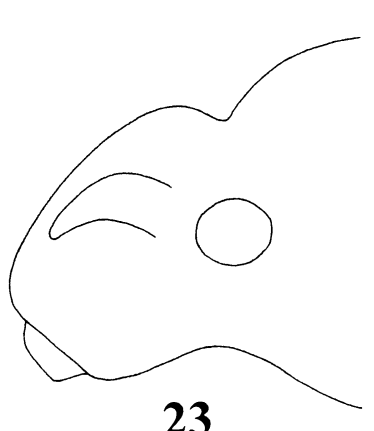

23

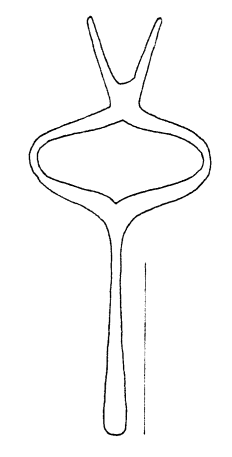

26

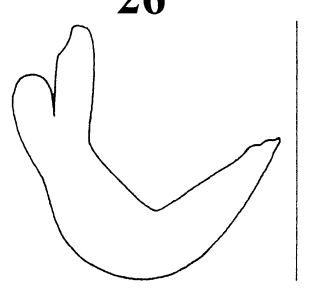

28

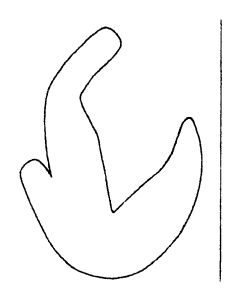

36

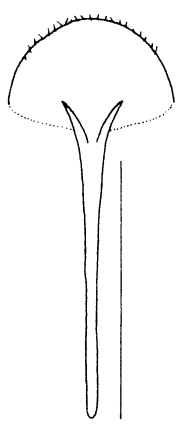

37

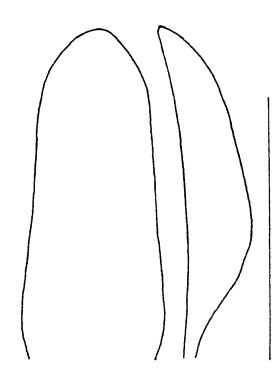

35

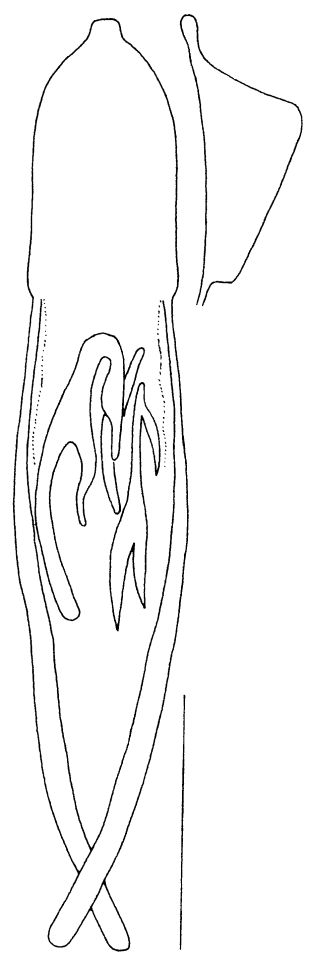

25

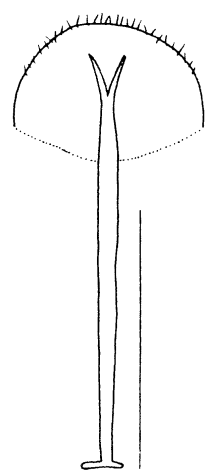

29

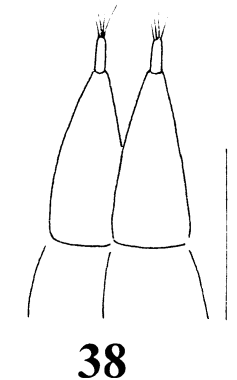

Figs 22-38. Structural details of Coniophloeus gen. n. Figs 22-30: Coniophloeus robustus sp. n. 22 - head with rostrum, dorsal view, scale $=1 \mathrm{~mm} ; 23$ - head with rostrum, lateral view, scale as in dorsal view; $24-$ apex of right protibia, scale $=0.50 \mathrm{~mm} ; 25-$ penis in ventral and lateral view, scale $=0.50 \mathrm{~mm} ; 26$ - tegmen in dorsal view, scale $=0.50 \mathrm{~mm} ; 27-$ sternite IX of male including hemisternites in dorsal view, scale $=1.00 \mathrm{~mm} ; 28-$ spermatheca, scale $=0.50 \mathrm{~mm} ; 29-$ sternite VIII of female, dorsal view, scale $=0.50 \mathrm{~mm} ; 30-$ ovipositor, dorsal view, scale $=0.25 \mathrm{~mm}$. Figs 31-38: C. squalidus (Boheman). $31-$ head with rostrum, dorsal view, scale $=1 \mathrm{~mm} ; 32$ - head with rostrum, lateral view, scale as in dorsal view; 33 - apex of right protibia, scale $=0.50 \mathrm{~mm} ; 34$ - abdominal ventrites, scale $=1$ $\mathrm{mm} ; 35$ - penis in ventral and lateral view, scale $=0.50 \mathrm{~mm} ; 36$ - spermatheca, scale $=0.50 \mathrm{~mm} ; 37$ - sternite VIII of female, dorsal view, scale $=0.50 \mathrm{~mm} ; 38-$ ovipositor, dorsal view, scale $=0.25 \mathrm{~mm}$. 
Type material. Lectotype (sex unknown): "Typus [red label, p] / Terra Caffrar. Eckl. et Zeyh. [hw] / LECTOTYPUS Trachyphloeus squalidus Boheman, Borovec, Skuhrovec des. 2017 [red label, p] / Gen. nov. squalidus (Boheman) Borovec, Skuhrovec det. 2017" (NHRS, Schoenherr's coll.).

Additional material examined. $2 q$, S. Af. [South Africa] $(\mathrm{BMNH}) ; 1 \delta^{\lambda}$, [South Africa] Cap [Cape, probably Cape Peninsula in Western Cape], Drége [lgt.] (SDEI); 1 $\hat{\jmath}$, Afr. m. [South Africa] (MNBG).

Redescription. Body length 3.66-4.19 mm. Body (Fig. 5) dark brownish to blackish, only clubs and tarsi paler, brownish; incrustate with indistinct appressed vestiture of oval scales except clubs and tarsi, 5-6 scales across width of one elytral intestria; setae on elytra semi-erect, conspicuous, long, moderately slender, subspatulate, in regular row on interstriae, slightly longer than half width of one interstria, intervals between setae slightly larger than setal length; setae on pronotum similar but densely irregularly scattered, semi-appressed and slightly broader; on head and rostrum similar but semi-appressed and distinctly shorter; femora, tibiae, scapes and funicles with very slender, long, semi-erect setae.

Rostrum (Figs 31, 32) 1.11-1.14× wider than long, in basal half with sides concave, then widely rounded around antennal insertions, at apical third equally wide as at base. Epifrons narrow, $0.6 \times$ as wide as rostrum in middle, with sides slightly concave, at base distinctly narrower than space between eyes, weakly longitudinally depressed; posteriorly V-shaped, separated from head by deep transverse furrow; beneath scales weakly shiny, finely sparsely granulate. Vertex irregularly and finely longitudinally striate, striae radiating from middle of base of epifrons. Scrobes dorsally reniform, distinctly visible in anterior half; laterally slender and short, narrow, weakly curved, directed to middle of eye, separated from it by wide squamous stripe. Eyes small, weakly convex, dorsally scarcely prominent from outline of head; laterally circular, placed in middle of head. Head wide, widest at base, distinctly tapering anteriorly with slightly convex sides, interocular space very wide.

Antennae moderately robust; scapes weakly curved before middle, gradually thicken apically, at apex $1.2 \times$ wider than clubs and as wide as middle of protibiae; funicles with segments 1 and 2 obconical, the others transverse; segment $11.5 \times$ longer than wide and $1.3 \times$ longer than segment 2 , which is $1.5 \times$ longer than wide, segments 3-61.6× wider than long, segment $71.7-1.8 \times$ wider than long; clubs short, $1.4 \times$ longer than wide, only slightly wider than last funicular segments.

Pronotum (Fig. 5) 1.72-1.75× wider than long; lateral margins weakly rounded in basal two thirds, at apical third conspicuously constricted; disc regularly convex; base weakly arched; in lateral view weakly convex; beneath scales moderately shiny, finely and regularly granulate.

Elytra (Fig. 5) oval, 1.16-1.22 $\times$ longer than wide with weakly rounded sides, laterally convex.

Protibiae (Fig. 33) at apex outer side enlarged, armed with 4 connected spines on outer corner, 2 connected spines in middle and 2 smaller isolated spines on inner side, plus mucro; spines yellowish, mucro brownish. Apical surface of metatibiae glabrous. Tarsi with segment 2 $1.3 \times$ wider than long; segment $31.4 \times$ wider than long and $1.2-1.3 \times$ wider than segment 2 ; onychium long, $1.8-1.9 \times$ longer than segment 3 ; claws shortly fused at base, distinctly divergent, brownish.

Penis (Fig. 35) ventrally moderately long and slender, widest at base, weakly evenly tapering apically, apex rounded; laterally slightly curved, widest at base, evenly tapering apically, tip not extended.

Spermatheca (Fig. 36) with cornu short and wide, almost straight, evenly tapering apically; corpus long; ramus small, about as wide as long; nodulus extremely long, about as long as cornu, tubular, distinctly curved in middle. Gonocoxites (Fig. 38) subtriangular with moderately long apical styli. Sternite VIII (Fig. 37) with plate $1.5 \times$ wider than long, with apodeme terminating in basal half.

Remarks. This species is distinguishable from all others except $C$. alternans sp. n. by its long semi-erect elytral setae, dorsally clearly visible scrobes, long rostrum, basally straight scapes and glabrous apical surface of the metatibiae, and from $C$. alternans sp. n. by elytral setae on all intervals.

\section{Coniophloeus alternans sp. $\mathbf{n}$.}

(Figs 1, 6-11)

ZooBank taxon LSID:

97AB340D-F618-4922-9FB8-CAD2541CB30F

Type locality. South Africa, Eastern Cape, Port Elizabeth.

Type material. Holotype: $\stackrel{N}{ }$, Süd Afrika [South Africa, Eastern Cape] / Algoa Bay [Port Elizabeth now] / 22.10.[18]95 / Dr. Brauns [lgt.] // G.A.K. Marshall / Coll. / B.M. 1950-255 (BMNH). Paratypes: 3 , , Capland [South Africa, Eastern Cape] / Algoa Bay [Port Elizabeth now] / Dr. Brauns [lgt.] // G.A.K. Marshall / Coll. / B.M. 1950-255 (BMNH).

Description. Body length 3.25-3.78, holotype $3.25 \mathrm{~mm}$. Body (Fig. 1) dark brownish to blackish, only clubs somewhat paler, brownish; incrustate with indistinct appressed vestiture. Setae on elytra semi-erect, conspicuous, long, moderately slender, subspatulate, in regular row only on odd interstriae, each seta slightly longer than half width of one interstria, intervals between setae somewhat larger than setal length; setae on pronotum similar but semi-appressed and slightly wider, densely irregularly scattered; on head and rostrum similar, but semi-appressed and distinctly shorter; on femora, tibiae, scapes and funicles very slender, long, semi-erect.

Rostrum (Figs 6, 7) 1.05-1.08 $\times$ wider than long, basal half with concave sides, then widely rounded around antennal insertions, in apical third equally wide as at base to $1.05 \times$ wider. Epifrons narrow, $0.6 \times$ wider than rostrum in the middle, with sides slightly concave, at base distinctly narrower than space between eyes, weakly longitudinally depressed; posteriorly U-shaped, separated from head by deep transverse furrow, beneath scales weakly shiny, indistinctly sparsely granulated; vertex irregularly and finely longitudinally striate, striae radiating from middle of base of epifrons. Scrobes dorsally reniform, clearly visible on 
anterior half; laterally slender and short, weakly curved, directed to ventral border of eye, separated from it by wide squamous stripe. Eyes small, weakly convex, dorsally scarcely prominent from outline of head; laterally circular, placed in middle of head. Head wide, widest at base, distinctly tapering anteriorly with sides slightly convex, vertex very wide.

Antennae moderately robust; scapes (Fig. 6) weakly curved before middle, gradually thickened apically, at apex $1.1 \times$ wider than clubs and as wide as middle of protibiae; funicles with segments 1 and 2 obconical, the others transverse; segment 1 1.2-1.3 $\times$ longer than wide and 1.3-1.4× longer than segment 2 , which is $1.2-1.3 \times$ longer than wide, segments 3-5 1.5-1.6× wider than long, segment $61.7 \times$ wider than long, segment $71.8 \times$ wider than long; clubs short, $1.3 \times$ longer than wide, only slightly wider than last funicular segments.

Pronotum (Fig. 1) 1.68-1.77× wider than long, at basal two thirds widest and slightly tapering anteriorly, with weakly rounded sides, apical third conspicuously constricted; disc regularly convex; base weakly arched; in lateral view weakly convex; beneath scales moderately shiny, finely and regularly granulate.

Elytra (Fig. 1) oval, 1.16-1.19× longer than wide, with weakly rounded sides, laterally convex.

Protibiae (Fig. 8) with outer side at apex enlarged, armed with 4 connected spines on outer corner, 2 connected spines in middle and 2 smaller isolated spines on inner side, plus mucro; spines yellowish, mucro brownish. Apical surface of metatibiae glabrous. Tarsi with segment 2 $1.4 \times$ wider than long; segment $31.4-1.5 \times$ wider than long and $1.2-1.3 \times$ wider than segment 2 ; onychium long, $1.7 \times$ longer than segment 3 ; claws fused at base, distinctly divergent, brownish.

Penis (Fig. 9) ventrally short and wide, widest at base, with weakly rounded sides, apex widely rounded; laterally almost straight, widest at base, apex tapers apically with shortly extended tip.

Spermatheca not examined. Gonocoxites (Fig. 11) short and wide, subtriangular, with short, slender apical styli. Sternite VIII (Fig. 10) with plate $2.5 \times$ wider than long, apodeme terminating on basal half of plate.

Etymology. The Latin name refers to the raised elytral setae, forming rows only on alternate odd interstriae.

Remarks. The holotype lacks the right funicle with club, left mesotarsus and the whole right hind-leg. This species differs from all others except $C$. squalidus by the long semi-erect elytral setae, the dorsally clearly visible scrobes, a longer rostrum, the basally straight scapes and the glabrous apical surface of the metatibiae, and from $C$. squalidus by having semi-erect elytral setae only on the odd interstriae.

\section{Coniophloeus oberprieleri sp. $\mathbf{n}$.}

(Figs 2, 12-17)

ZooBank taxon LSID:

CD09D5B6-2410-4AC0-8C32-9E3D07CB041F
Type locality. South Africa, Eastern Cape, Humansdorp.

Type material. Holotype: + , South Africa, C. P. [Cape Province, Eastern Cape now] / Humansdorp. 34.02S / 24.46E. 27.xi.1983 / R. Oberprieler [lgt.] // National Coll. / of Insects / Pretoria, S. Afr. (SANC).

Description. Body length 4.19 mm. Body (Fig. 2) dark brownish, only clubs slightly paler brownish, except clubs and tarsi with appressed small rounded scales, leaving distinct interspaces, 6-8 scales across width of one interstria; on elytra semi-appressed, in dense regular row on each interstria, subspatulate, widest before tip, finely longitudinally striate, about as long as half the width of one interstria, intervals between setae slightly larger than setal length; on pronotum similar but wider, densely irregularly scattered; on head and rostrum similar but distinctly shorter; on scapes, femora and tibiae very dense, semi-appressed, as long as setae on head with rostrum; on funicles more slender.

Rostrum (Figs 12, 13) wide and short, 1.79× wider than long, widest at base, here $1.09 \times$ as wide as at apex, basal half regularly tapering anteriorly, apical half regularly rounded. Epifrons moderately narrow, at base slightly narrower than space between eyes, with sides concave, in middle $0.6 \times$ wider than the base of the rostrum; beneath scales moderately shiny and roughly irregularly punctate, with posterior border almost straight, separated from head by deep transverse furrow; head longitudinally striate, striae radiating from middle of base of epifrons. Scrobes not visible dorsally; laterally short and wide, curved, directed towards eyes and separated from them by narrow squamous stripe. Eyes small, convex, dorsally clearly visible, prominent from outline of head; laterally circular, placed at middle of head. Head short and wide, weakly tapering anteriorly, laterally distinctly obliquely declivous to base of rostrum. Vertex wide.

Antennae robust; basal quarter of scapes (Fig. 12) distinctly S-shaped, apical three quarters weakly curved, widest at apical third, here 1.7-1.8 $\times$ wider than clubs and about as wide as middle of protibiae; funicle with segments 1 and 2 obconical, the others transverse; segment $11.4 \times$ longer than wide and $1.1 \times$ longer than segment 2 , which is $1.4 \times$ longer than wide, segments 3-5 $1.5 \times$ wider than long, segment $61.7 \times$ wider than long, segment $71.9 \times$ wider than long; clubs short, $1.6 \times$ longer than wide, visibly wider than last funicular segments.

Pronotum (Fig. 2) very wide, $2.24 \times$ wider than long, widest at base, basal half weakly tapering anteriorly with slightly rounded sides, apical half conspicuously tapering anteriorly, distinctly constricted behind anterior border; disc regularly domed; base bisinuate; hind corners pointed; in lateral view weakly convex.

Elytra (Fig. 2) long-oval, 1.28 $\times$ longer than wide, lateral margins subparallel, straight, disc convex in lateral view. Seven inner intervals with small, indistinct tubercles on posterior declivity.

Apical part of protibiae (Fig. 14) conspicuously widened laterally to significant, rounded projection, armed by fringe of connected, very short, brownish 8 spines, inner part of 
protibiae armed with 9 short, brownish, isolated spines and short brownish mucro. Apical surface of metatibiae densely squamous. Tarsi with segment $21.3-1.4 \times$ wider than long; segment $31.5-1.6 \times$ wider than long and 1.2-1.3× wider than segment 2 ; onychium moderately long, $1.6 \times$ longer than segment 3 ; claws shortly fused basally, moderately divergent, dark brownish.

Male genitalia unknown.

Female genitalia. Spermatheca (Fig. 15) with straight cornu; corpus robust, long; ramus straight, about twice as long as wide, obliquely placed; nodulus also straight, longer and wider than ramus. Gonocoxites (Fig. 17) subtriangular, evenly tapering apically, with long apical styli. Sternite VIII (Fig. 16) with plate $1.8 \times$ wider than long, with apodeme terminating on apical half of plate.

Etymology. This newly described species is dedicated to my friend and colleague Rolf Oberprieler (CSIRO, Australia), collector of the holotype and outstanding expert on South African weevils.

Remarks. C. oberprieleri $\mathrm{sp}$. n. is easily distinguishable from all other species of the genus mainly by having the outer protibial margin enlarged to form a laterally prominent rounded projection, the pronotum $2.2 \times$ wider than long, as wide as the elytra, widest at the base and with the posterior corners pointed, elongate posteriorly.

\section{Coniophloeus obrieni sp. $\mathbf{n}$.}

(Figs 3, 18-21)

ZooBank taxon LSID:

28AE5A53-BD63-4B1B-86CA-C8FEA13EAEFB

Type locality. South Africa, Western Cape, Hex River Valley. Type material. Holotype: $\hat{\sigma}$, [South Africa, Western Cape] Hex Riv.[er] / Jan[uary] [18]85 (SANC).

Description. Body length 4.63 mm. Body (Fig. 3) dark brownish; except for the tarsi covered with small, irregularly angular appressed scales leaving slender interspaces, 7-8 scales across width of one elytral interstria; on elytra semi-appressed, subspatulate, widest before tip, finely longitudinally striate, slightly shorter than half width of one interstria, in 1-2 irregular dense row(s), intervals between setae slightly longer than setal length; on pronotum similar but slightly wider, very densely irregularly scattered; on head and rostrum similar, but shorter; on scapes, femora and tibiae slender, dense, subspatulate, semi-appressed.

Rostrum (Figs 18, 19) $1.35 \times$ wider than long, widest at base, regularly tapering anteriorly with sides straight, at base $1.08 \times$ as wide as at apex. Epifrons widest at base, here as wide as space between eyes, regularly tapering anteriorly with sides slightly concave, in middle $0.7 \times$ wider than the width of the middle of the rostrum; beneath scales roughly punctate, longitudinally deepened with narrow median longitudinal stria, with base weakly arched, separated from head by deep transverse furrow; head shiny, distinctly longitudinally striate, striae radiating from middle of base of epifrons. Scrobes not visible dorsally; laterally curved, moderately short, distinctly enlarged posteriorly, posterior part as wide as diameter of eye, directed towards eyes and separated from them by narrow squamous stripe. Eyes small, flat, dorsally scarcely visible; laterally placed at middle of head. Head short and wide, tapering anteriorly; laterally declivous to base of epifrons; interocular space wide.

Antennae moderately robust; basal third of scapes (Fig. 18) weakly S-shaped, gradually thickening apically, at apex widest, slightly narrower than middle of protibiae. Funicles and clubs missing in holotype.

Pronotum (Fig. 3) very wide, 1.79 $\times$ wider than long, widest at middle, with distinctly rounded sides, weakly tapering posteriorly and conspicuously tapering anteriorly, constricted behind anterior margin; disc regularly convex; base slightly arched; laterally weakly convex.

Elytra (Fig. 3) long-oval, 1.30× longer than wide, lateral margins subparallel, straight, disc flat in lateral view.

Outside and inside of the apex of protibiae (Fig. 20) enlarged, armed with 4 connected yellowish brown spines on outer lobe and 9 isolated spines of different sizes on anterior border, plus brownish curved short mucro. Apical surface of metatibiae densely squamous. Tarsi with segment 2 $1.3 \times$ wider than long; segment $31.4 \times$ wider than long and $1.4 \times$ wider than segment 2 ; onychium short, $1.2 \times$ longer than segment 3 ; claws shortly fused at base, moderately divergent, brownish.

Penis (Fig. 21) ventrally long and slender, with base and apex similarly wide with weakly concave sides, apically rounded with short, subtrapezoidal tip; laterally wide with ventral surface straight and dorsal surface curved, regularly tapering apically with tip pointed.

Female genitalia unknown.

Etymology. The new species is named in honour of the eminent entomologist Charles W. O'Brien (Phoenix, Arizona, USA).

Remark. The holotype lacks both funicles and clubs, the complete left anterior and posterior legs and tarsus of the right middle leg. Its locality was explained to me by Riaan Stals and Elisabeth Globbelaar (SANC), as: "The Hex River Valley in the current Cape Winelands District Municipality, Western Cape Province; in 1885 located in the colony of the Cape of Good Hope. The only settlement in the Hex River Valley is the small town of De Doorns

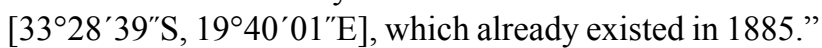
Coniophloeus obrieni sp. n. is easily distinguishable from all other species of the genus mainly by the pronotum being widest in the middle, the laterally flat elytra with straight sides and the eyes barely visible dorsally.

\section{Coniophloeus robustus sp. $\mathbf{n}$.}

(Figs 4, 22-30)

ZooBank taxon LSID:

643DF653-9135-41DE-BEB0-05AAAD1A1795

Type locality. South Africa, Eastern Cape, Baviaanskloof, Geelhoutbos.

Type material. Holotype: $\widehat{\partial}$, S. Afr. [South Africa, Eastern Cape]; Baviaanskloof / Geelhoutbos; $300 \mathrm{~m} / 33.38 \mathrm{~S}-24.14 \mathrm{E}$ // 11.11.2015; E-Y: 3977 / sifting forest litter / leg. Ruth Müller (TMSA). Paratype: $5 \hat{\jmath}, 4 q$, the same data as holotype (TMSA); $1 \hat{0}, 1$, [ [South Africa, Eastern Cape], Algoa Bay [Port Elizabeth 
now] / Capland / [18]98.5.1 / Dr. Brauns [lgt.] // G.A.K. Marshall / Coll. / B.M. 1950-255 (BMNH).

Description. Body length 3.78-5.56 mm, holotype 4.63 mm. The whole body (Fig. 4) dark brownish to blackish, only clubs slightly paler, brownish, except for clubs and tarsi covered with small, irregularly angular appressed scales, leaving very slender interspaces, 7-8 scales across width of one interstria; setae on elytra semi-appressed, finely longitudinally striate, widest at apex, slightly shorter than half width of one interstria, in one regular row on each interstria, intervals between setae about twice the setal length, on disc slender, subspatulate, in posterior declivity twice as wide as those on disc, spatulate; on pronotum, head and rostrum similar, but densely irregularly scattered, on pronotum as long as on elytra, on head and rostrum shorter; on scapes, femora and tibiae similar, on funicles appressed, more slender.

Rostrum (Figs 22, 23) very wide and short, 1.53-1.67× wider than long, weakly regularly tapering anteriorly. Epifrons wide, at base almost as wide as space between eyes, in basal half distinctly tapering anteriorly, in apical half subparallel-sided, with sides distinctly concave; beneath scales moderately shiny, irregularly roughly punctate, longitudinally shallowly deepened with posterior border arched with short concavity at middle, separated from head by deep transverse furrow. Head irregularly longitudinally roughly striate, at middle of anterior part with small and deep triangular incision. Scrobes dorsally almost not visible; laterally short and wide, subtriangular, distinctly curved, posteriorly about as wide as diameter of eye, directed towards eye, separated from them by wide squamous stripe. Eyes small, weakly convex and weakly prominent from outline of head; laterally circular, in middle of head. Head wide and short, weakly tapering anteriorly, interocular space very wide.

Antennae extremely robust; basal third of scapes (Fig. 22) conspicuously S-shaped, apical two thirds weakly curved, widest at apical third and here twice as wide as clubs and about as wide as middle of protibiae; funicle with segments 1 and 2 obconical, the others transverse; segment $11.6-1.7 \times$ longer than wide and $1.1 \times$ longer than segment 2 , which is $1.4-1.5 \times$ longer than wide, segments $3-41.5 \times$ wider than long, segments 5-7 1.7-1.8 $\times$ wider than long; clubs short, $1.3 \times$ longer than wide, about as wide as last funicular segments.

Pronotum (Fig. 4) 1.64-1.83× wider than long, basal half the widest, here subparallel-sided with slightly rounded sides, apical half conspicuously constricted; disc regularly convex; base weakly arched; in lateral view weakly convex.

Elytra (Fig. 4) long-oval, 1.20-1.31× longer than wide, with sides weakly rounded, laterally convex; at posterior declivity with small, sometimes indistinct tubercles, in some specimens bigger on odd intervals than on inner ones.

Wide outer and inner sides of apices of protibiae (Fig. 24) armed with 15-20 yellowish short spines, on outer and middle part aggregated in two groups, on inner part isolated, with short brownish mucro at inner corner. Apical sur- face of metatibiae densely squamous. Tarsi with segment 2 1.7-1.8 $\times$ wider than long; segment $31.5 \times$ wider than long and $1.2-1.3 \times$ wider than segment 2 ; onychium moderately long, $1.5 \times$ longer than segment 3 ; claws shortly fused at base, moderately divergent, brownish.

Penis (Fig. 25) ventrally short, widest at base, tapering apically with slightly concave sides, apex rounded with very short, obtuse tip; laterally wide, ventral surface straight, dorsal surface of anterior third distinctly enlarged, tip distinctly extended.

Female genitalia. Spermatheca (Fig. 28) with cornu almost straight; corpus long; ramus about $1.5 \times$ longer than wide, apically rounded; nodulus twice a long as ramus, straight. Gonocoxites (Fig. 30) subtriangular, evenly tapering apically, with short apical styli. Sternite VIII (Fig. 29) with plate $1.4 \times$ wider than long; apodeme terminating on apical half.

Etymology. The dumpy, robust body suggested the Latin name of this new species.

Remarks. This is the largest species in this genus, similar only to $C$. obrieni $\mathrm{sp}$. n. in its epifrons being basally as wide as the space between the eyes Distinguishing characters between these two species are cited in the key to species.

\section{Key to the species of Coniophloeus gen. $\mathbf{n}$.}

1 Elytra with short semi-appressed subspatulate setae, setae at most as long as half the width of one interstria (Figs 2-4). Dorsally the scrobes are almost invisible (Figs 12, 18, 22). Rostrum 1.3-1.8 $\times$ wider than long (Figs 12, 18, 22). Scapes at base weakly or distinctly S-shaped (Figs 12, 18, 22). Apex of protibiae armed with at least 6 spines (Figs 14, 20, 24). Apical surface of metatibiae densely squamous................... 2

- Elytra with long semi-erect subspatulate setae, slightly longer than half width of one interstria (Figs 1, 5). Scrobes dorsally clearly visible (Figs 6, 31). Rostrum $1.1 \times$ wider than long (Figs 6, 31). Scapes at base straight (Figs 6, 31). Apex of protibiae armed with at most 6 spines, not including mucro (Figs 8, 33). Apical surface of metatibiae glabrous .............. 4

2 Protibiae at apex enlarged into laterally prominent rounded projection (Fig. 14). Pronotum $2.2 \times$ wider than long, as wide as elytra, widest just at base, with posterior corners pointed, elongated posteriorly (Fig. 2). Epifrons at base narrower than space between eyes (Fig. 12). Length $4.2 \mathrm{~mm}$.

C. oberprieleri $\mathrm{sp} . \mathrm{n}$. Protibiae at apex laterally slightly enlarged (Figs 20, 24). Pronotum 1.6-1.8 $\times$ wider than long, slightly narrower than elytra, widest before base, with posterior corners rounded, not elongated posteriorly (Figs 3, 4). Epifrons at base as wide as space between eyes (Figs 18, 22) ....................................... 3

3 Rostrum shorter and wider, 1.5-1.7× wider than long (Fig. 22). Scapes extremely robust, at base distinctly S-shaped, with apical third the widest (Fig. 22). Pronotum widest at basal third (Fig. 4). Elytra with slightly rounded sides, laterally convex (Fig. 4). Eyes dorsally clearly visible (Fig. 22). Length $3.8-5.6 \mathrm{~mm}$.. C. robustus sp. n. - Rostrum longer and slenderer, $1.35 \times$ wider than long (Fig. 18). Scapes moderately robust, at base weakly S-shaped, widest at apex (Fig. 18). Pronotum widest in middle (Fig. 3). Elytra with sides straight, laterally flat (Fig. 3). Eyes dorsally scarcely visible (Fig. 18). Length $4.6 \mathrm{~mm}$......C. obrieni $\mathrm{sp} . \mathrm{n}$. 
4 Elytral setae uniformly semi-erect on all interstriae (Fig. 5). Penis ventrally longer, apex narrowly rounded (Fig. 35). Length 3.6-4.2 mm. C. squalidus (Boheman)

- Elytral setae semi-erect only on odd interstriae (Fig. 1). Penis ventrally shorter, apex widely rounded (Fig. 9). Length 3.2$3.8 \mathrm{~mm}$ C. alternans sp. $\mathrm{n}$

ACKNOWLEDGEMENTS. I thank M. Barclay (BMNH), L. Behne (SDEI), J. Bergsten (NHRS), R. Müller (TMSA), R. Stals (SANC) and M. Uhlig (MNBG) for the loan of specimens for this study. I also thank C. O'Brien for reading and commenting on the manuscript and correcting the English and P. Krásenský (Chomutov, Czech Republic) for the habitus photographs. I thank three anonymous reviewers for valuable critical comments. The study was supported by grant CIGA No. 20174313 of the Czech University of Life Sciences Prague, Faculty of Forestry and Wood Sciences.

\section{REFERENCES}

Borovec R. \& Meregalli M. 2013: Soil insect research in South Africa. 1. A new genus of terricolous weevils with four new species from the Richtersveld National Park (Coleoptera: Curculionidae: Entiminae: Trachyphloeini). — Zootaxa 3646 501-515.

Borovec R. \& Oberprieler R.G. 2013: Afrophloeus, a new genus of African weevils of the tribe Embrithini (Coleoptera: Cur- culionidae: Entiminae), with description of a new species and notes on the composition of Embrithini. - Zootaxa 3693: 365-378.

Borovec R. \& Skuhrovec J. 2017: Systematic position of the Afrotropical species described in Trachyphloeini (Coleoptera: Curculionidae: Entiminae). — Zootaxa 4344: 522-540.

LonA C. 1937: Curculionidae: Otiorrhynchinae II. In Schenkling S. (ed.): Coleopterorum Catalogus, Pars 160. W. Junk, s-Gravenhage, pp. 1-412.

Oberprieler R.G., Anderson R.S. \& Marvaldi A.E. 2014: 3. Curculionoidea Latreille, 1802: Introduction, Phylogeny. In Leschen R.A.B. \& Beutel R.G. (eds): Handbook of Zoology, Arthropoda: Insecta; Coleoptera, Beetles. Vol. 3: Morphology and Systematics (Phytophaga). Walter de Gruyter, Berlin, Boston, pp. 285-300.

SCHOENHERR C.J. 1842: Genera et species curculionidum, cum synonymia hujus familiae. Species novae aut hactenus minus cognitae, descriptionibus a Dom. Leonardo Gyllenhal, C. H. Boheman, et entomologis aliis, illustratae. Vol. 7(1). Roret, Paris, $479 \mathrm{pp}$.

SeIdLitz G. 1868: Die Otiorhynchiden s. str. nach den morphologischen Verwandtschaftsverhältnissen ihres Hautscelet's vergleichend dargestellt. - Berl. Entomol. Z. 12: 1-153.

Received October 17, 2018; revised and accepted April 29, 2019 Published online June 20, 2019 